\begin{tabular}{ccc}
\hline International Journal of Engineering \& Technology, $7(3.36)(2018) 134-136$ \\
SPC \\
Website w ww. sciencepubco.com/index.php/IJET \\
Research paper
\end{tabular}

\title{
Strengthening Youths Skill: Wiring Workshop in Rural Area
}

\author{
Hazilah Mad Kaidi $^{1 *}$, Nor Fazilah Mohd Hashim ${ }^{1}$, Mohd Nabil Muhtazaruddin ${ }^{1}$, Nurul Aini Bani ${ }^{1}$, Norulhusna \\ Ahmad $^{1}$, Norliza Mohamed ${ }^{1}$, Rafizah Musa' ${ }^{1}$, Fatimah Salim ${ }^{1}$
}

${ }^{1}$ Razak Faculty of Technology and Informatics, Universiti Teknologi Malaysia, Kuala Lumpur, Malaysia.

*Corresponding author E-mail: hazilah.kl@utm.my

\begin{abstract}
Youth is known as an energetic people with a high potential, and eager to try something new. Therefore, it is such a loss if the abilities that they have been wasted and not fully utilised in a proper way. Project of the electrical wiring workshop is one of the great initiatives as it provides a knowledge base and develops skills in technology and engineering especially in a rural area. In addition, the workshop also aims to develop interpersonal, communication and lifelong learning skills. The ability of youth also increases in generating side income and entrepreneurship nowadays. Through involvement, participants in the wiring workshop have been exposed with a variety of basic installation and wiring techniques whereby they are able to shape their personalities with the advantage of skills in technology and engineering acquired. As a result, return on investment (RoI) can be achieved in the workshop which being conducted at Kampung Pasir Puteh, Kalumpang Hulu Selangor, Malaysia.
\end{abstract}

Keywords: wiring skill, rural, wiring, adolescent, workshop, electric, network

\section{Introduction}

Community-based activities require involvement and participation among active community members in the overall work process. Community engagement is a key mechanism in community empowerment and development. Therefore, the availability of their power and potentials can be expanded so they are able to plan, implement, make decisions and creating future development according to their own needs and needs without having to intervene maximum from out-side parties [1-2]. As a result, community work is difficult to be proved as it is if the community itself did not get involved or simply being an observer or recipient [3-4]. In this project, the target group is youths age between 17 to 30 years living in the selected rural area. As a result, 21 numbers of youth have been participated with various educational backgrounds, jobs and family institutions.

The main objective of the project is to provide a knowledge base and develop skills in technology and engineering. In addition, it is also intended to develop interpersonal, communication and lifelong learning skills as well as to increase the ability to generate side income by venturing into entrepreneurship. Throughout the project, participants were exposed to the basic techniques of single-phase electrical installation at residential or other premises area assisted by industry named OHM Electrical. In addition, the project also prepares youth to deepen their knowledge and also develop personal personalities with the advantage of skills in technology and engineering gained. Furthermore, value added in the field of entrepreneurship was also being applied for selfdevelopment. The techniques that's taught to the participants were very useful because it can be used for daily practices as well as a source of income if they were really mastered and proficient in the techniques taught.

This paper is organised as follows. In Section 2, the background of research is presented. Section 3 presents the process flow, from the preparation process until the monitoring process of the work- shop. Besides, In Section 4 explains the achievement and the analysis result while in Section 5 concludes the paper

\section{Research Background}

The community project is an effort undertaken with certain goals and objectives. Among the objectives of the project is helping to ease the burden, give benefits, and improve well-being of the community. The strengthening youth skills project is a collaborative project between Universiti Teknologi Malaysia (UTM) and the National Blue Ocean Strategy (NBOS) fundraiser under Ministry of Higher Education (MOHE) and Industrial Community Network Center (CCIN) Universiti Teknologi Malaysia. The project is devoted to the teenagers and youngsters who were interested in learning the skills offered. The electrical wiring workshop is being conducted to fulfill the research achievement index of rural development at Kg Pasir Puteh, Kalumpang, Hulu Selangor. The workshop could provide the youths with the opportunity to apply the technique for career purposes besides cultivating interest in skills and entrepreneurship.

During the workshop at Kalumpang, Hulu Selangor, all participants were together contributed towards the successful of the workshop. The committee of Kampung Pasir Puteh Kalumpang had prepared the site of the program including the hall, equipment required, work-force, and advisory services. Razak Faculty of Technology and Informatics as a main organizer provides transportation and equipment and facilitators throughout the workshop as well as the OHM Electrical. The involvement of OHM Electrical, as a Bumiputera company in the success of the program has brought participants closer to the real situation of the relevant workplace. Their company practices as a 'Bumiputera' company involves in the entrepreneurship was also applied throughout the workshop.

In order to ensure that the process of financing is successful, the development must go towards sustainability. The process of com- 
munity development does not end with just being able to meet the needs of the community to improve their standard of living, it is also towards sustainability that can be constructed in a number of ways such as increasing the capacity of community leadership, enabling partnerships between organizations, appointing new members to be engaged in the process, creating a self-contained program, preserving the ecological, economic, and environment of the community. In other words, the process of funding is not only measured on the outcome of a product, such as the number of houses constructed, employment opportunities created, reduced crime rates, but it also based on the community's ability to continue the process to sustain community development [5]

\section{Methodology}

This study was a survey study using quantitative approaches to identify the level of involvement of youths in rural areas who are interested in learning the skills offered in the electrical wiring workshop. The first activity undertaken before the workshop begins is to identify the village area and the potential location to be engaged. Next, a visit to the village to identify suitable location for committee meetings between facilitators and villagers before the workshop started. After that, the provision of learning modules, survey forms and equipment were prepared. The survey is taken before, during, and after the workshop. The survey form is being analysed after the workshop completed. The survey is comprises a set of questions and it is a tool that specifically designed to collect information for analysis purposes that answered the research questions [6-7]. Finally, monitoring program is being confirmed a month after the workshop was completed.

The location of the study was in the countryside in Kampung Serting Ulu, Kalumpang, Hulu Selangor. Respondents involved in this study comprised youths from various backgrounds which considering their education, employment and family institutions in each selected study location. In addition, the census approach has been used 21 respondents were involved in this study. The study uses a 'Thurstone Scale' for skills assessment purposes. Assessment was measured by two aspects, which first is the level of respondent's skill level and second was the assessment of the effectiveness level of the workshop. The respondents' profiles and comments have been reviewed and considered. Fig 1 shows some activities conducted during the workshop.

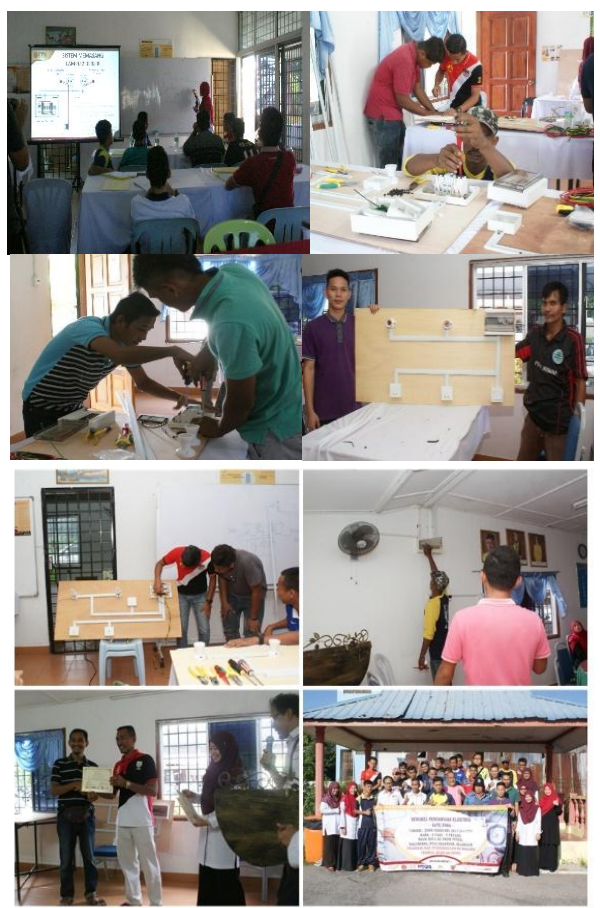

Fig. 1: Activities of youths during the electrical wiring workshop.

\section{Result and Discussion}

Table 1 tabulates the demographic information of electrical wiring workshop participants. Majority of the participants were teenagers and youth which $90 \%$ of them at the age between 16 years old to 25 years old. Half of the participants are working, while some of them are from the secondary school students, a few of them are waiting for SPM result and jobless. Only $24 \%$ of the participants are married. In addition, the highest education levels of the participants are at SPM level which up to $90 \%$ of them. From the statistic, it shows that, we need to enforce our priority to help and improve youth development especially in the rural area. Knowledge and technology transfer are the best methods to help them to enhance their skills.

Table 1: Demographic Information Pattern

\begin{tabular}{lc|l}
\hline $\begin{array}{l}\text { Background of Partic- } \\
\text { ipants }\end{array}$ & Percentage & Additional info \\
\hline Working & $50 \%$ & $\begin{array}{l}\text { Salary RM } 500- \\
\text { RM 2000 } \\
16-17 \text { years old } \\
\text { Salary RM 1001- } \\
\text { RM 2000 } \\
\text { Ttudent } \\
\text { Married }\end{array}$ \\
SPM level & $50 \%$ & $\begin{array}{l}\text { tion } \\
10 \% \text { are }>25 \text { years } \\
\text { old }\end{array}$ \\
\hline
\end{tabular}

Fig 2 shows the increased skill and confidence of participants before and after the workshop in Kalumpang. The enhancement of the skills and confidence of the participants in the workshop comprises increases of understanding and knowledge more than before the program, enhancing the confidence of applying knowledge rather than prior to joining workshops, enhancing the desire for entrepreneurial knowledge, increased confidence in pursuing work related wiring systems, readiness and confidence to carry out activities or course-related projects, readiness to follow the workshop's continued workshop and the effectiveness of the workshops. The workshops were evaluated in three categories namely before, during and after the implementation of the workshop. The registration form was distributed to the participants before the program begin to assess the background of the participants. This was followed by a survey form and feedback form to measure the level of knowledge, skills and satisfaction of participants before and after the workshop. Project monitoring after the program was implemented to assess the achievement of project targets and objectives including RoI. The workshop generally shows a significant improvement in the skills and confidence of participants before and after participating in the workshop.

Fig 2 shows the increased skill and confidence of participants before and after joining the electrical wiring workshops in $\mathrm{Ka}$ lumpang. There were 21 numbers of participants has been participated in the workshop. Each graph shows an increased in the transfer of knowledge as well as the confidence of participants in learning the skills. The findings of the first study are related to increased knowledge and understanding of participants compared to before the workshop. From the questionnaires distributed, $81 \%$ of the participants did not have an early exposure to the electrical wiring system knowledge before they joined the workshop. After the workshops, there has been an increase in understanding and knowledge of three times on the electrical wiring among the participants. The next findings are related to participants' confidence in applying what has been learned from the workshops. At first, only $50 \%$ of the participants were confident of applying wiring system wiring without the help of others. 


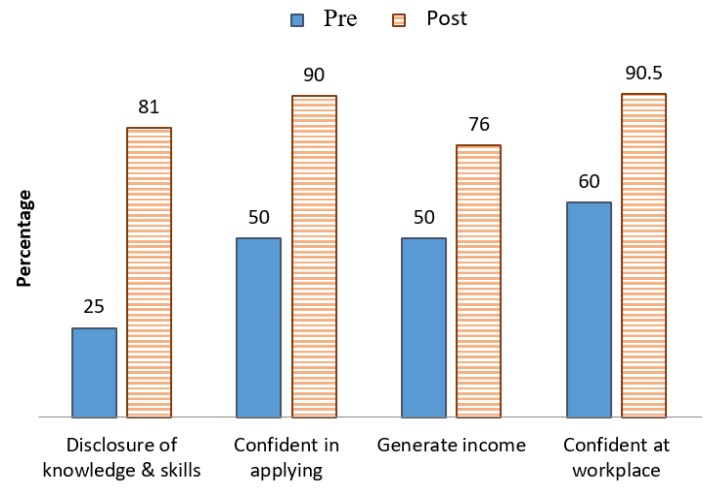

Fig 2: Result of Pre and Post-Survey on Electrical Wiring Workshops in Kalumpang

After participated in the workshop, $90 \%$ of the participants were more likely to apply what they have learned individually. The findings of the third study are about improving the participants' desire to generate income using the knowledge obtained from the workshop. After the workshop, $76 \%$ of the participants are confident and willing to use the knowledge acquired from the workshop to generate income and sustain their lives. From the result, lucrative income could be generated in their daily lives as not everyone has the skills and expertise in that area. The findings of the next study are about increasing the confidence of participants using the knowledge to work in the work environment related to the wiring system. After participated in the workshop provided, $90.5 \%$ of the participants were more confident about using the knowledge from the workshop to take on the work environment related to the wiring system.

The latest findings from the electrical wiring workshop are the participants' opinions on the success and benefits of the workshop that have been held entirely. For the electrical wiring workshop in Kalumpang, 95\% of the participants' perspective agreed that the workshop was a successful and very beneficial not only to them but also to other youth mostly. All participants were satisfied with the workshops that have been carried out and hoping that further transfer of knowledge will be implemented after the program. Participants also suggested that the workshop could be implemented over a longer period as more time are required to complete the wiring work for each module.

After the workshop, there was a drastic increase in participants by up to $85 \%$. The next findings are related to the participants' confidence in applying what has been learned from the workshops. In the early stages, only $5 \%$ of the participants were confident of applying for wiring works without the help of others. After the workshop, $95 \%$ of the participants were confident in applying the wiring works individually. The findings of the third study are about improving the participants' desire to generate income using the knowledge obtained from the workshop. After the workshop, $95 \%$ of the participants were confident and willing to use the knowledge gained to generate income and sustain their lives. The findings of the next study are about increasing the confidence of participants using knowledge to pursue work-related network wiring systems. This could generate lucrative income in their daily lives as not everyone has the skills and expertise in the field of wiring the network system.

Project monitoring was conducted to assess the achievement of project targets and objectives including ROI. The electrical wiring workshop at Kalumpang had achieved ROI whereas one of the participants, Faizul Izudin Bin Baharuddin, has successfully acquired an electrical wiring work worth nearly RM500 a week as his additional income. Thus, the total ROI earned is RM4000 per month. He had received offers to do a wiring not only at his surrounding house area, but also in the city area. He was successfully repaired the broken fan wiring in a Balai Raya during the workshop in the testing session. His confident and knowledge as well as passion in wiring helped him to continuously being involved in this kind of job scope. The success of the project had also gained media coverage published online at Bernama on Thursday, June 15,2017 . As a result of the program's continuity, $50 \%$ in the provision of workshop materials had been supported by the NBOS4 fund and it can be re-applied for the continuity in another rural area program. Knowledge in wiring skills, confident and entrepreneurship are some of the generic skills development that has been produced for social impact of the workshop.

\section{Conclusion}

At the end of the project implementation, monitoring has been achieved reaching the target of RoI in the electrical wiring workshop when some of the participants managed to obtain wiring work. Overall, the trainers and facilitators of the workshop had successfully delivered the content of the course effectively. This can be seen through the analysis results that have been stated. The course content of the workshop was sufficient to enable participants to understand the correct concepts, methods and hands-on of the wiring for level 1 . The trainer or facilitator ratio to the participants is 1:2. It also plays an important role in helping the success of the workshop. Each participant can effectively implement each module efficiently. However, registration number of youths involved in this workshop was difficult to obtain at the first start. The village committee was help us to increase the registration number until the day of the workshop was conducted.

In the development, community empowerment occurs when they have demonstrated the ability to identify problems, find resources, improve skills and experiences, implement, lead and mobilize all active community members in every program implemented for mutual benefits [5]. Hence, it is hoped that the skills-enhancing program among youths would be able to benefit fully in terms of job opportunities, skills and economic development as well as environment sustainability. Such community programs should be continued and expanded for the community to become more vulnerable with various skills and could reduce the unemployment rate among the youths people.

\section{Acknowledgement}

The authors would like to thank for the support given towards this research by the National Blue Ocean Strategy (NBOS) from Ministry of Higher Education Malaysia, Universiti Teknologi Malaysia (UTM), grant Vot: R.K130000.7840.4L204, Razak Grant UTM R.K130000.7740.4J314, and to all authors who contribute in the rural area research for youths development.

\section{References}

[1] Aref, A. A. The Theoretical and Conceptual Framework and Application of Community Empowerment. Journal of American Science 186-195. (2011).

[2] Aref, A. A. Empowerment as an Approach for Community Development in. World Rural Observations, 63-68. (2009).

[3] Bahari, D. A. Prinsip-Prinsip Kerja Komuniti ++ (SukarelawanMalaysia.com, Ed.) Sukarelawan Malaysia. (2012, March 17).

[4] Kwok Chin Hoe, A. A. Peranan Organisasi Berasaskan Komuniti (OBK) dalam pembangunan komuniti: Suatu pemerhatian awal (The Role of Community-Based Organization (CBO) in community development: A preliminary observation). Malaysian Journal of Society and Space. (2015).

[5] Fauziah Ani, A. A. Pendekatan Pendayaupayaan dalam Pembangunan Komuniti: Satu Analisa dari . Malaysian Journal of Social Sciences and Humanities, Volume1, Issue1, 36- 44. (2016).

[6] Siti Hajar Abu Bakar, N. O. Intervensi Sosial Untuk Komuniti Tersisih: Ke Arah Pembangunan Ummah (Social Intervention For Marginalized Community: Towards The Development Of Ummah). Journal Hadhari: An International Journal. (2012).

[7] Suhaili, s. Sumbangan-Sumbangan Belia Dalam Pembangunan Negara. Fasilitator Bahasa Melayu. (2011). 